\title{
In defence of the case study methodology for research into strategy practice
}

Jeff Hughes and Joe McDonagh*

Trinity College Dublin, Ireland

Abstract: This paper aims to illustrate how the case study methodology may be used in novel and productive ways for research into strategy practice. Instigated by the quest for a research design that could target the 'practice' of strategic information systems planning (SISP), a review of the strategy-as-practice (SAP) literature uncovered parallels with the SISP domain from a methodological standpoint. A SAP perspective was employed in conjunction with the case study methodology to investigate SISP (the strategy practice) on the part of senior managers (the practitioners) at the meso level (the level of praxis). Ultimately, this approach was found to offer original insights and uncover valuable new directions for future academic enquiry.

Keywords: case study; methodology; strategy as practice; strategic information systems planning

(C) De Gruyter Open Sp. z 0.0.

\section{RESEARCH CONTEXT AND BACKGROUND}

The objective of the wider study was to answer the research question 'How is strategic information systems planning (SISP) practised by senior managers?' The research involves investigating the practice of SISP by senior managers set in a public service context, thus answering enduring calls for studies into information systems (IS) strategising behaviour within organisations located in a public service context (Rocheleau, 2007; Rubin, 1986). An effective IS strategy is recognised as contributing to improved firm performance (Leidner et al., 2011; Ravichandran and Lertwongsatien, 2005), as well as being a key enabler of business strategy (Preston and Karahanna, 2006). IS strategy has been a significant concern for practice, dominating management agendas in recent decades (Teubner, 2013) and becoming integral to business positioning and processes (Stace et al., 2012).

The specific purpose of this article is to elucidate the methodological approach employed to achieve the wider study's goal. The strategy-as-practice (SAP) and SISP literature sets are the two core strands of literature informing the research question as posed. Each literature set has made a unique contribution to the formulation and execution of the chosen research design.

\section{THE REVIEWED LITERATURE}

An overview of each domain of literature now follows, with particular emphasis upon the core constructs that informed the approach to enquiry.

\section{The SAP domain}

Vaara and Whittington (2012) trace the origins of the wider practice perspective back to the works of Wittgenstein (1951) and Heidegger (1962). Wittgenstein is viewed as having the most significant influence upon the placement of the practical dimension of philosophy front and centre of philosophical debate in modern times (Deslandes, 2011). The foundations established by Wittgenstein's work were built upon by Heidegger, with the former's assertions 
being untangled and given structure by the latter (Chia, 2006). Subsequent years saw a proliferation of practicebased theories across the social sciences (Vaara and Whittington, 2012), with its emergence in the strategy field occurring in just the past couple of decades. The suggestion was that strategy research could be advanced through the adoption of social theories of practice (Hendry, 2000; Hendry and Seidl, 2003), most prominently those of Giddens (1976), Maclntyre (1985), Foucault (1980), Bourdieu (1990), and De Certeau (1984), and the influence of this work is evident in the present-day literature (Chia, 2006; Deslandes, 2011; Splitter and Seidl, 2011). Research into SAP has drawn upon a diverse foundation of practice theories emanating from within the social sciences. However, from a review of the extant SAP literature, it would appear that activity theory (Jarratt and Stiles, 2010; Jarzabkowski, 2003; Johnson et al., 2003) and structuration theory (Feldman and Orlikowski, 2011; Jarzabkowski, 2008) have gained the most traction amongst the pre-eminent authors.

SAP is 'concerned with the doing of strategy; who does it, what they do, how they do it, what they use and what implications this has for shaping strategy' (Jarzabkowski and Spee, 2009: 69). It is heavily focussed on the social dimension of the strategy-making endeavour by 'bringing human actors and their actions and interactions to the centre stage of strategy research' (Jarzabkowski and Spee, 2009: 70). In targeting the everyday minutiae of what strategy practitioners actually do, strategy may be understood as something people do rather than something that firms in their markets have (Jarzabkowski and Seidl, 2008: 1391). The key tenets of the practice perspective are its '3Ps' of practice, praxis, and practitioners (Whittington, 2006). The level at which praxis transpires is categorised into micro, meso, and macro levels. Strategic episodes and the wider social environment both form additional signposts for the collection and analysis of data during a SAP-based study. The following sections provide an overview of each of these integral constructs.

\section{Practices}

Strategy practices are viewed by Jarzabkowski and Whittington (2008: 101) as involving the 'various routines, discourses, concepts and technologies through which this strategy labour is made possible - not just obvious ones such as strategy reviews and off-sites, but also those embedded in academic and consulting tools (Porterian analysis, hypothesis testing, and so on) and in more material technologies and artefacts (PowerPoints, flip-charts, and so on)'. In a sense, they provide the boundaries within which strategic activity occurs, imbuing behavioural, cognitive, procedural, discursive, and physical resources upon strategists (Jarzabkowski et al., 2007). However, they do not enforce rigid boundaries but rather allow for iteration and adaptation (Vaara and Whittington, 2012). Thus, there exists an entwinement between strategy practices and strategy praxis, with practitioners playing somewhat of a mediating role between both concepts and the extent to which each shapes the other.

\section{Praxis}

At its broadest level, praxis refers to the 'vast social enterprise of day-to-day activity' (Campbell-Hunt, 2007: 794). It comprises the 'interconnection between the actions of different, dispersed individuals and groups and those socially, politically, and economically embedded institutions within which individuals act and to which they contribute' (Jarzabkowski et al., 2007: 9). Such a definition is highlighted as being pertinent, as it captures both how practice can be operationalised at multiple levels, i.e. from macro to micro, as well as its inherent adaptability as it shifts through the interactions between these levels.

\section{Practitioners}

'Strategy's practitioners are defined widely, to include both those directly involved in making strategy - most prominently managers and consultants - and those with indirect influence - the policy-makers, the media, the gurus and the business schools who shape legitimate praxis and practices.' (Jarzabkowski and Whittington, 2008: 101102)

Practitioners are interrelated with both practices and praxis as it is the prevalent organisational practices that engender strategy practitioners with agency in regard to how they act and behave (Jarzabkowski et al., 2007). Practitioners represent a suitable unit of analysis for a SAP-based study, as it is they who shape the strategy that will ultimately determine the future direction of the organisation.

\section{A levels perspective}

SAP-based studies may employ a multi-level perspective upon praxis, with three such levels identified within the SAP literature (Jarzabkowski and Spee, 2009). Micro refers to studies concerning an individual's or a group's 
experience of a particular episode, i.e. a decision or a meeting. Meso refers to studies located at an organisational or sub-organisational level, i.e. a change programme or a strategy process. Macro studies explore praxis at an institutional level, i.e. attempting to explain praxis within a specific industry.

\section{The concept of the strategic episode}

Within the SAP literature resides the recurrent theme of the strategic episode. Incidents of strategic episodes are an explicit component of Whittington's (2006) framework. An episode can be defined as a 'sequence of communications structured in terms of its beginning and ending' (Hendry and Seidl, 2003: 176), the beginning and ending of which is not only observable by the external observer but also by the communication within the sequence. Indeed, conversational and discourse analysis have proven valuable research topics within the SAP domain due to their apparent linkages to the wider social component of strategising (Balogun et al., 2014; Hardy and Thomas, 2014).

\section{The social dimension of strategising}

A SAP lens allows researchers to more closely examine and describe exactly what is involved in organisational phenomena as they unfold (Sandberg and Dall'Alba, 2010). However, it also encapsulates the grounding of these micro activities within their wider social context (Bürgi et al., 2005; Palmer and O'Kane, 2007), i.e. 'actors in their micro-situations are not acting in isolation but are drawing upon the regular, socially defined modes of acting that arise from the plural social institutions to which they belong' (Jarzabkowski et al., 2007: 6), thus linking the micro to the macro context (Oliver and Bürgi, 2005; Regner, 2008; Seidl and Whittington, 2014; Whittington et al., 2011).

There exist explicit calls for the adoption of a SAP perspective within the SISP domain (Teubner, 2013), as it has the potential to result in the design of better strategising processes and practices (Bryson et al., 2010).

\section{The SISP domain}

When referring to SISP, it is the planning or formulation stage of IS strategising that is paramount. The remit of SISP research is elucidated by Segars et al. (1998; quoted in Brown, 2004: 20), who define its focus as being 'on the strategic to tactical level' and that 'in terms of scope, it is organisational; in perspective of top management, in terms of level of abstraction, more conceptual than physical, and in time frame, medium to long'. Ward and Peppard (2002: 118) proffer a similar definition, viewing it as 'thinking strategically and planning for the effective long-term management and optimal impact of information in all its forms: information systems (IS) and information technology (IT)...' SISP is more complex than an exercise, during which the technical merits of an array of alternatives are evaluated. Rather, in congruence with SAP studies, the social dimension of the process (Avgerou and McGrath, 2007) is of particular importance due to the disparate organisational backgrounds of those involved. This lends itself to examination under the 'sociological eye' (Whittington, 2007) of a practice-based perspective, and thus highlights the inherent compatibility evident between both research domains.

While there exists evident entanglement across the various streams of literature as it pertains to IS strategy at large, a delineation is provided by Chen et al. (2010) through their categorisation of three closely related avenues of research. They include SISP (Brown, 2004; Merali et al., 2012; Teubner, 2013), the alignment of business strategies and IS strategies (Chan and Reich, 2007; Henderson and Venkatraman, 1993; Kearns and Lederer, 2000), and the use of IS for competitive advantage (Eng and Luff, 2011; Okpattah et al., 2014; Piccoli and Ives, 2005).

As alluded to by Chen et al. (2010), the boundaries between each literature set are blurred. While a large body of the reviewed SISP literature focusses upon SISP tools, the practitioners involved in SISP, and the organisational traits conducive to effective SISP, so too does a significant portion of literature pertain to planning for IS strategic alignment or planning for the use of IS to obtain competitive advantage. This is not surprising as each of these dimensions can be viewed as a core SISP component and the complete disaggregation of each of these three streams of literature would prove an unrealistic goal due to the inherent commonality between each of them (Chen et al., 2010). Such a finding is supported by Earl $(1989,1993)$, who proposes that SISP targets the alignment of investment in IS with business goals and the exploitation of IS for competitive advantage. Lederer and Sethi's (1996: 35) definition of SISP as being 'the process of identifying a portfolio of computer-based applications that will assist an organisation in executing its business plans and realising its business goals' also corroborates this finding. 


\section{SUPPORT FROM THE EXTANT LITERATURE FOR THE RESEARCH APPROACH FROM A METHODOLOGICAL STANDPOINT}

As detailed, the two core pillars of literature that have been used to inform the research question are the SAP and SISP literature sets. From a methodological standpoint, they add support for the inherent suitability of employing the case study methodology for an investigation into the chosen research topic.

\section{Methodological analysis of the SAP literature}

Remaining true to the very essence of a practice perspective to research, i.e. proclivities towards the actual 'doing' of strategy work on the part of practitioners, the dominant research methodologies are conducive to an in-depth analysis of the focus of investigation (Table 1). Of the 48 empirical papers reviewed featuring some form of primary data collection, either a single-case study (21) or a small number of case studies (17) were the dominant approaches employed. Ethnographic studies accounted for a further nine studies, again highlighting both a requirement and a desire on the part of researchers to get as close as possible to the data.

Table 1. Analysis of the sap literature

\begin{tabular}{|c|c|}
\hline Number of sources & 120 \\
\hline \multirow{2}{*}{ Source classification } & Books: 10 \\
\hline & Journals: 110 \\
\hline \multirow{2}{*}{ Content analysis } & Conceptual: 62 \\
\hline & Empirical: 48 \\
\hline \multirow{4}{*}{ Methodological approach } & Single-case study: 21 \\
\hline & Multiple-case study: 17 \\
\hline & Ethnography: 9 \\
\hline & Survey: 1 \\
\hline \multirow{4}{*}{ Sectoral analysis } & Private: 24 \\
\hline & Public: 18 \\
\hline & Mixed: 5 \\
\hline & Voluntary: 1 \\
\hline \multirow{4}{*}{ Geographic location analysis } & Europe: 41 \\
\hline & U.S.A.: 4 \\
\hline & Australasia: 2 \\
\hline & Mix: 1 \\
\hline \multirow{4}{*}{ Unit of analysis } & Senior managers: 24 \\
\hline & Middle managers: 1 \\
\hline & Lower-level employees: 1 \\
\hline & Mix: 22 \\
\hline
\end{tabular}

The prescriptive literature often points to the suitability of an ethnographic approach to practice-based research (Chia and MacKay, 2007; Fenton and Langley, 2011; Jarzabkowski et al., 2007; Miettinen et al., 2010; Rasche and Chia, 2009; Whittington, 2004). However, the prevalence of ethnographic studies does not quite match the sentiment of goodwill expressed towards its applicability to practice-based research, an anomaly most likely manifested out of the inherent difficulties associated with conducting an ethnographic study. Such difficulties include gaining the requisite access to candidate organisations, the immense personal commitment required of the researchers during prolonged periods of immersion within the field, the validity of the research approach itself, and the practical fear of having to justify oneself to reviewers and editors for departing from the more conventional research approaches of survey or interview-based research (Myers, 1999; Watson, 2011).

Finally, just a single survey-based study was conducted by Gunn and Williams (2007), which again highlights the inherent bias towards a qualitative approach within practice-based research. 


\section{Methodological analysis of the SISP literature}

The substantially larger body of empirically grounded SISP literature in comparison to its SAP counterpart (126 versus 48 , respectively), combined with its more expansive time frame, allowed for a more substantial macro-level analysis to be conducted. Examination of the featured 126 empirical studies from a methodological perspective yields some interesting findings (Table 2).

Table 2. Methodological analysis of the SISP literature

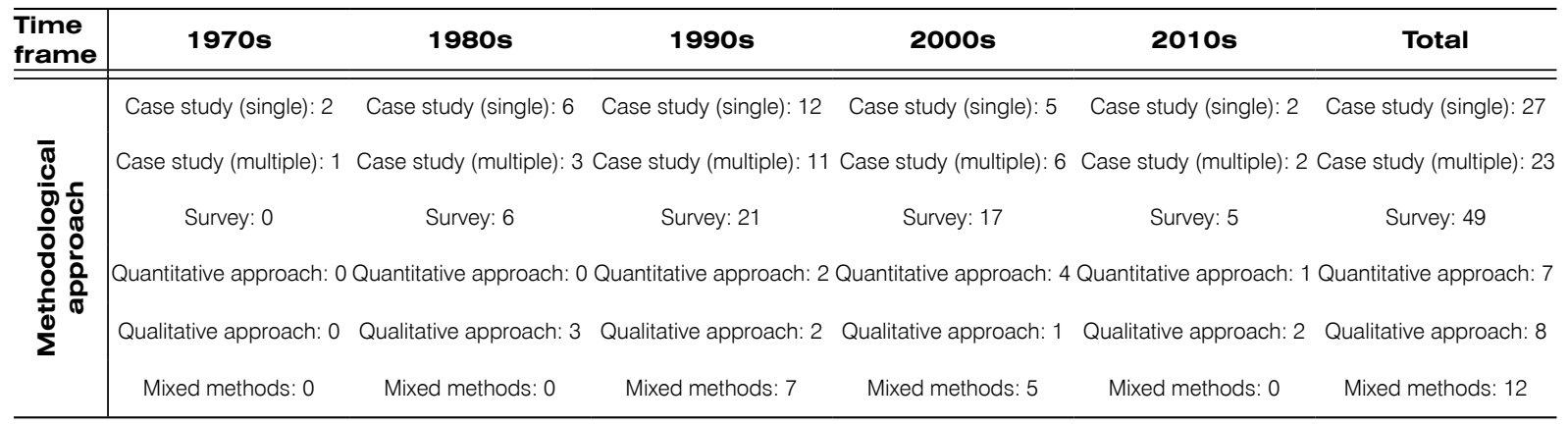

While a number of reviews of IS research at large (Avison et al., 2008; Chen and Hirschheim, 2004; Hirschheim and Klein, 2012; Orlikowski and Baroudi, 1991; Palvia et al., 2007; Vessey et al., 2002; Williams et al., 2009) have produced varying results due to the specific literature sets under review, i.e. journal specific (Palvia et al., 2007; Avison et al., 2008) or region specific (Chen and Hirschheim, 2004), the current review of research focussed upon SISP produced encouraging results. It would appear that earlier calls for a more varied approach to IS research (Galliers, 1993; Mingers, 2001; Orlikowski and Baroudi, 1991) have been somewhat answered, with the dominance of the positivist, survey-based approach being somewhat eschewed within the SISP domain. This is perhaps understandable due to the nature of the focus of investigation and the inherent difficulty associated with quantifying the phenomenon. Thus, it lends itself to exploratory research of a qualitative nature, and hence the prevalence of case-based research is logical. The findings are in tandem with the work of Hirschheim and Klein (2012), which also found a growing acceptance within the IS research community of interpretive research approaches using a variety of qualitative methods.

Within the reviewed literature, the case study approach is the most prevalent, accounting for 50 studies. A closer inspection reveals that single-case studies (27) slightly out-matched a multiple-case study design (23). The survey approach - with 49 studies - was narrowly eclipsed into second position. Mixed methods (e.g. Applegate and Elam, 1992) proved to be the third most frequently employed methodological approach, accounting for 12 studies. Finally, research employing either some form of qualitative approach (8), such as focus groups or interviewing (Lederer and Mendelow, 1989), or quantitative methods (7), such as statistical analysis (Barua et al., 1991), completed the literature set.

\section{THE CHOSEN METHODOLOGY: CASE STUDY INCORPORATING A SAP PERSPECTIVE}

It is a widely held tenet of social research that it is the research question that drives ensuing decisions relating to the selection of a suitable research approach (Bryman, 2007; Denzin and Lincoln, 2005; Senn, 1998). Therefore, a methodology was required that could satisfy the following:

- $\quad$ Provide a holistic approach to answering a 'how'-type question.

- Allow for an exploratory study seeking to build theory.

- $\quad$ Embrace an investigation into a social activity, i.e. senior managers' practice of SISP.

Based on such criteria, the case study methodology adopting a SAP perspective was decided upon as an appropriate research approach. 


\section{The case study methodology: overview}

The scope of a case study is defined by Yin (1994: 13) as follows: 'A case study is an empirical inquiry that investigates a contemporary phenomenon within its real-life context, especially when the boundaries between phenomenon and context are not clearly evident'. Gerring (2004: 342) believes a case study is best defined as 'an intensive study of a single unit for the purpose of understanding a larger class of (similar) units'. Eisenhardt (1989: 534) simply defines the case study as 'a research strategy which focuses on understanding the dynamics present within single settings'.

Case studies are a commonly employed empirical strategy in IS research (Lee and Hubona, 2009; Orlikowski and Baroudi, 1991) and have become increasingly popular within the field (Doolin, 1996; Steventon et al., 2012). They can be used to achieve various research aims, inclusive of providing rich descriptions of phenomena in context and developing or testing theory (Darke et al., 1998; Eisenhardt, 1989). Case studies are acknowledged to possess an advantage when engaging in research that is exploratory in nature (Gerring, 2004). It has become an increasingly attractive approach for researchers looking to investigate the development, implementation, and use of IS within organisations (Darke et al., 1998). Theory building from case-based studies is growing in acceptance (Hoon, 2013), with a large number of influential works emanating from the approach (Eisenhardt and Graebner, 2007). As an exploratory study, the research also benefits from the potential richness of the accrued data, which is a major strength of the case-based approach (Siggelkow, 2007). Kuhn (1987) opines that a discipline without a substantial body of thoroughly executed case studies is a discipline without a systematic production of exemplars, and that such a discipline is an ineffective one.

\section{Case selection and number of cases}

The value of the research is dependent on more than just the number of cases chosen. The quality of the cases selected and the researchers' analytical and investigative abilities are of equal, if not greater, importance (Perry, 1998). The choice of case sites should involve discretion and judgement (Amaratunga and Baldry, 2001). Cases should be selected for their ability to contribute to the overall investigation rather than a logic predicated on convenience (Poulis et al., 2013; Stake, 1995). The identification of a population of possible case study sites is a good starting point and is crucial to the case selection process. An appropriate population 'helps to define the limits for generalising the findings' (Eisenhardt, 1989: 537). From the finalised population, theoretical sampling may be used for case selection, i.e. cases are chosen for theoretical, not statistical reasons (Glaser and Strauss, 1967), with the goal being to extend the emergent theory (Eisenhardt, 1989). Given that each case would emanate from the population of Irish public service organisations, the study's case selection criteria were as follows:

- Public service organisations: each case must reside within the Irish public service domain and thus satisfy the evident lack of IS research set within a public service context. A reason for exclusion under this dimension would be if the case were located within a sector other than the public service, e.g. the private sector, the voluntary sector, and so on.

- The role of IS: the organisation will ideally view IS as a core business function, the establishment of which can be ascertained through initial contact with candidate case sites. In such organisations, the need for SISP and senior managers' participation therein is likely to be increased. An unsuitable case under this criterion would be an organisation that views its IS department as a non-core function, requiring day-to-day oversight, but lacking any strategic intent.

- The practice of SISP: evidence must exist within each case site of a commitment to SISP. This can be measured by the presence or lack thereof of IS strategies, IS strategy reviews, and other IS strategy-related documentation. An example of an unsuitable case under this dimension would be an organisation devoid of such materials or indeed any tangible evidence as to the existence of the practice of SISP.

- The role of senior managers: cases are chosen in which senior managers are actively involved in the practice of SISP. An example of an unsuitable case under this criterion would be an organisation that outsources the planning of its IS function to a third party, effectively eliminating senior managers from SISP.

A key consideration in the design of a research strategy is whether to employ a single- or a multiple-case approach (Yin, 2009). A single case can allow for the collection of extremely rich data due to its explicit focus on just one research site (Franklin et al., 2014), being particularly appropriate for extreme or exemplary situations to which the researcher has gained access (Zivkovic, 2012). However, such an approach is not without its potential drawbacks. A number of such concerns are raised by Lee (1989) and Gable (1994), with a single case study's lack of generalisability (Tsang, 2014) identified as the principal concern with such a design (Van de Ven and Huber, 1990). Conversely, a multiple- 
case approach may diminish the potential richness of the data collected with each additional case added, but equally increases - in theory - generalisability as more cases are incorporated into the study. Multiple cases typically provide a stronger base for building theory (Benbasat et al., 1987; Yin, 2009), tending to result in 'more robust, generalisable, and testable theory than single-case research' (Eisenhardt and Graebner, 2007: 27). A multiple-case study design also allows for cross-case comparison (Darke et al., 1998; Tsang, 2013), which further contributes to the building of rich theory (Benbasat et al., 1987). Perry (1998) depicts the many differing views in regard to the ideal number of cases, ranging from two at a minimum up to 15 at the maximum end of the scale.

Two cases were decided upon for the current study. The researchers believe two cases strike a reasonable balance between having the necessary breadth from which to build credible theory and also allowing for the depth to pursue rich data due to the exploratory nature of the research. From the researchers' review of the SAP literature, it is apparent that studies of this nature have a strong tendency to feature either a single or a small number of case studies. The reasons for such were realised during data collection and analysis. More than two cases could have resulted in data management issues: the employed two cases proved challenging by themselves due to the large quantity of data accrued for each case site. The researchers' viewpoint, having now completed the study and being in a position to stand back and view it from a more objective position, is that an unnecessary quest to increase the number of cases would have proved detrimental to the quality and depth of the research. The researchers were unwilling to compromise on this attribute of the study.

\section{Data collection}

Multiple data collection methods are normally employed during case-based research (Benbasat et al., 1987; Venkatesh et al., 2013). Table 3 details the sources of evidence that can be utilised during casework and those used for the current study. This multi-method approach ameliorates the validity of the results due to the triangulation of findings (Eisenhardt, 1989). It can also prove to be highly synergistic by improving data accuracy and limiting the researchers' biases (Miles and Huberman, 1994). Sources of data include organisational documentation, archival records, interviews, direct observation, and physical artefacts (Benbasat et al., 1987), with the principal goal being to collect rich data that accurately represent the phenomena under investigation.

Table 3. Data collection: sources of evidence (adapted from Yin, 2009)

\begin{tabular}{|c|c|c|c|}
\hline $\begin{array}{l}\text { Source of } \\
\text { evidence }\end{array}$ & Strengths & Weaknesses & Included in the current study? \\
\hline $\begin{array}{l}\text { Documentation } \\
\end{array}$ & $\begin{array}{l}\text { Stable - can be reviewed repeatedly. } \\
\text { Unobtrusive - not created as a result } \\
\text { of the case study. } \\
\text { Exact - contains exact names, } \\
\text { references, and details of an event. } \\
\text { Broad coverage - long span of time, } \\
\text { many events and settings. }\end{array}$ & $\begin{array}{l}\text { Retrievability - can be difficult to find. } \\
\text { Biased selectivity, if collection is incomplete. } \\
\text { Reporting bias - reflects (unknown) bias of } \\
\text { author(s). } \\
\text { Access - may be deliberately withheld. }\end{array}$ & $\begin{array}{c}\text { YES } \\
\text { Examples - minutes of meetings, written } \\
\text { reports, articles appearing in mass media. } \\
\text { Solid foundational evidence for case, used } \\
\text { for corroboration. }\end{array}$ \\
\hline Archival records & $\begin{array}{l}\text { (Same as those for documentation) } \\
\text { Precise and usually quantitative. }\end{array}$ & $\begin{array}{l}\text { (Same as those for documentation) } \\
\text { Accessibility due to privacy reasons. }\end{array}$ & $\begin{array}{l}\text { YES (limited) } \\
\text { Examples - service records showing } \\
\text { number of clients served, organisational } \\
\text { records showing budget and personnel } \\
\text { records. }\end{array}$ \\
\hline Interviews & $\begin{array}{l}\text { Targeted - focus directly on case } \\
\text { study topics. } \\
\text { Insightful - provide perceived causal } \\
\text { inferences and explanations. }\end{array}$ & $\begin{array}{l}\text { Bias due to poorly articulated question. } \\
\text { Response bias. } \\
\text { Inaccuracies due to poor recall. } \\
\text { Reflexivity - interviewee gives what } \\
\text { interviewer wants to hear. }\end{array}$ & $\begin{array}{c}\text { YES } \\
\text { Example - In-depth interviews conducted } \\
\text { with } 31 \text { interviewees across both case sites. } \\
\text { Exhaustive - all key personnel targeted } \\
\text { were interviewed. No further suggestions } \\
\text { proffered by interviewees. }\end{array}$ \\
\hline $\begin{array}{l}\text { Direct } \\
\text { observations }\end{array}$ & $\begin{array}{l}\text { Reality - cover events in real time. } \\
\text { Contextual - cover context of case. }\end{array}$ & $\begin{array}{c}\text { Time consuming. } \\
\text { Selectivity - broad coverage difficult without a } \\
\text { team of observers. } \\
\text { Reflexivity - event may proceed differently } \\
\text { because it is being observed. } \\
\text { Cost - hours needed by human observers. }\end{array}$ & $\begin{array}{l}\text { NO } \\
\text { Not employed due to issues of reflexivity. } \\
\text { The ability to gain the required access over } \\
\text { a sustained period of time also uncertain. }\end{array}$ \\
\hline $\begin{array}{l}\text { Participant- } \\
\text { observation }\end{array}$ & $\begin{array}{l}\text { (Same as above for direct } \\
\text { observation) } \\
\text { Insightful into interpersonal } \\
\text { behaviour and motives. }\end{array}$ & $\begin{array}{c}\text { (Same as above for direct observations) } \\
\text { Bias due to participant's/observer's } \\
\text { manipulation of events. }\end{array}$ & $\begin{array}{l}\text { NO } \\
\text { Not employed due to the potential bias that } \\
\text { such actions would have on the study's } \\
\text { findings. }\end{array}$ \\
\hline $\begin{array}{l}\text { Physical } \\
\text { artefacts }\end{array}$ & $\begin{array}{l}\text { Insightful into cultural features. } \\
\text { Insightful into technical operations. }\end{array}$ & $\begin{array}{l}\text { Selectivity. } \\
\text { Availability. }\end{array}$ & $\begin{array}{c}\text { YES } \\
\text { Example - The IS Strategy reports covering } \\
\text { 2010-2012 (Case 1) and 2011-2015 (Case } \\
\text { 2) and their associated materials. }\end{array}$ \\
\hline
\end{tabular}


Table 4 provides an overview of the secondary data sources collected for the current study. The multi-level data collection (Kozlowski et al., 2013) approach employed is commensurate with the adopted SAP lens, representing a further use of Jarzabkowski and Spee's (2009) construct of levels.

Table 4. Categorisation of secondary data sources

\begin{tabular}{lc}
\hline Context of origin & Number of documents \\
\hline \hline The European context & 12 \\
The public service context & 27 \\
The healthcare context & 20 \\
The host organisation context & 65 \\
\hline Total & 124 \\
\hline
\end{tabular}

Data sources were categorised based upon specified levels, i.e. the European context, the public service context, the healthcare context, and the context of both host organisations. This rudimentary yet effective SAPderived classification scheme proved a valuable organising mechanism for the wealth of collected data. Returning to the language of practice, the sources of secondary data from each of the European context, the public service context, and the healthcare context can be classified as emanating from the macro-level. The secondary data specific to both case sites are located at the meso-level. Thus, this process serves as an example of the SAP lens's pervasive role during the execution of the current study. The comprehensive, structured collection of secondary data provided a solid foundation from which to build upon during the course of subsequent fieldwork.

The study then employed semi-structured interviews (Mojtahed et al., 2014) that adhered to an agreed-upon protocol in relation to recording techniques, the descriptive process, whether or not feedback will be provided, and additional ethical concerns (Myers and Venable, 2014; Myers and Newman, 2007; Stahl et al., 2014). Guidelines for the conduct of the interview process were obtained from Kvale (1996), Myers and Newman (2007), and Hermanowicz (2002). Interview questions possessed characteristics of a SAP perspective in their focus upon the 3Ps of practice, praxis, and practitioner (Seidl and Whittington, 2014; Whittington, 2006), with each forming broad topics for discussion as they pertained to the practice of SISP within each host organisation.

In a review of case-based research in four leading IS journals from 1989 to 1993, Doolin (1996) discovered interviews to be the primary method of data collection. Interviews are also the most widely used qualitative data collection method, being extensively used in an array of disparate disciplines (Schultze and Avital, 2010). In their study of IS research articles that relied primarily on interviewing methods conducted from 2004 to 2008 , Schultze and Avital (2010) found that there was a near-three-fold increase in the frequency in which the method was deployed over the time frame of the study, increasing from 12 papers in 2004 to 35 in 2008. As opined by Hermanowicz (2002: 480 ), interviews have an ability to 'bring us arguably closer than many other methods to an intimate understanding of people in their social worlds', making it particularly appropriate for generating rich, qualitative data.

\section{The case study methodology: data analysis}

The coding strategy employed was that proposed by Maykut and Morehouse, (1994). Having spent time considering various coding techniques (Charmaz, 2006; Corbin and Strauss, 2008; Glaser and Strauss, 1967; Maykut and Morehouse, 1994), it became clear that all of them possessed an inherent similarity; phases predominantly involved an initial sorting of the data, consolidation and ordering of categories, and the search for linkages between and across higher-order categories from which the theory could emerge. The selected strategy was found to possess such traits and be highly rigourous in its approach.

Maykut and Morehouse's technique is largely based on the coding principles of grounded theory (Glaser and Strauss, 1967). It involves nine discrete cycles of analysis. At each stage of the analytical strategy, the researchers retained the use of the adopted SAP lens and its inherent levels perspective.

\section{A NOVEL APPROACH: THE INCORPORATION OF A SAP PERSPECTIVE}

The incorporation of a SAP perspective (Jarzabkowski and Spee, 2009; Johnson et al., 2007; Orlikowski, 2010; Whittington, 2006) for the chosen case study methodology manifested itself as a filter through which the data were collected and distilled. 
To clarify how the researchers used a SAP lens, the work of Orlikowski (2010) brings this particular element of the research strategy into focus. A clear differentiation exists between the use of formal practice theory (Bourdieu, 1990; Feldman and Orlikowski, 2011; Giddens, 1984; Schatzki, 1996) and the SAP-based approach utilised for the current study. Practice theory is concerned with 'practice as the principal constituent of social affairs, and thus a basic epistemic object of social theory' (Cecez-Kecmanovic et al., 2014: 815). Conversely, practice as a perspective may be viewed as an outlook that links macro and micro levels to assist in the conduct of research rather than the 'world-view' underpinnings of its philosophical counterpart. Orlikowski (2010) provides an illuminating delineation, including a third mode of engaging with practice in the form of practice as a phenomenon. The author's treatment of this subject matter has been adopted for use in the SAP domain.

- Practice as a phenomenon places its focus upon what happens 'in practice' and deep empirical engagement, recognising that there is often a large gap between the theories and frameworks proffered by researchers and the actual doing of practitioners 'in practice'. The techniques used to close this gap involve getting as close as possible to the lived reality, mostly through techniques akin to immersive participant observation and various forms of action research.

- Practice as a perspective, the mode employed for the current study, identifies it 'as a powerful lens for studying particular social phenomena' (Orlikowski, 2010; 25), with Orlikowski viewing its ascendency in more recent times as being an important departure from more traditional perspectives that tended to focus on either macro or micro-level dimensions. Practice as a perspective links the more mundane, micro-level activities of strategy practitioners with more macro-level structures and practices. A conceptual grounding in practice theories is a prerequisite, and given that the research is a strategy-focussed practice study, the utilisation of Whittington's (2006) 3Ps framework proved most appropriate in this instance.

- Finally, practice as a philosophy places practice at the fulcrum of one's own ontological belief system, and that 'all social reality is understood to be constituted in and through practices' (Orlikowski, 2010: 27). To distinguish this mode from the previous two, Orlikowski delineates them as follows; practice as a phenomenon is an empirical claim that practices matter and thus should form the basis of investigation into organisational phenomena. Practice as a perspective is a theoretical claim that practices shape reality and need to be explained through practice theoretic accounts of organisational reality. Lastly, practice as a philosophy is a 'meta-theoretical claim that practices are reality, and thus studies or organisations must be grounded ontologically, theoretically, and empirically in lived practice' (Orlikowski, 2010: 27).

Employing a practice-as-a-perspective approach for the wider study, the authors were able to avail of the ability to focus upon both macro-level contextual factors and more micro-level activity. Simultaneously, transparent linkages between both dimensions were discovered. Indeed, such linkages proved crucial in the exploration of senior managers' participation in the practice of SISP. Senior managers' micro activities were often influenced by macro-level practices and, conversely, there existed examples of micro activity infiltrating macro-level practice. Remaining true to a practice-as-a-perspective approach, the study was conceptually grounded in Whittington's (2006) framework, which provided the necessary lens through which to view the workings of such a duality.

\section{Justification for the adoption of a SAP perspective}

The use of a SAP perspective in conjunction with the case study methodology represents a deliberate, reasoned decision. There exist explicit calls for the adoption of a SAP perspective from within the IS domain (Peppard et al., 2014; Teubner, 2013). The recognition and uptake of the approach is evidenced in the 2014 special issue of the Journal of Strategic Information Systems, with Whittington's (2014) commentary in particular applauding the SISP and SAP joint agenda. Such publications elucidate the distinction bestowed upon the approach by the IS academic community. Further encouragement may be found from related disciplines to have adopted a practice approach, inclusive of leadership as practice (Raelin, 2011), accountancy as practice (Kornberger and Carter, 2010), business ethics as practice (Clegg et al., 2007), and marketing as practice (Browne et al., 2014).

Evidence exists within the extant SAP literature of the fortitude of the perspective. Johnson et al. (2007) proffer four such advantages. First, in its purest form, the practice perspective sheds light on the actual 'doing' of strategy, enriching our knowledge of the ways in which strategising actually takes place (Vaara and Whittington, 2012). Since this is what managers in a learning environment are concerned with mastering, it is highly beneficial to executive education. Second, it removes the level of abstraction associated with traditional strategy research, thus going deeper into the core issues within the field. Third, as demonstrated in Whittington's $(2002,2006)$ framework, a 
practice perspective can act as an integrating mechanism for the field of strategy research, whereby the central components can be interconnected into a coherent whole. So not only are more micro-level processes explored and detailed, but their linkages to the bigger macro-level picture may be traced in addition to the role of the strategy practitioners therein (Vaara and Whittington, 2012). Finally, the fourth advantage is a culmination of the previous three, in that strategy-as-practice research offers a new and exciting direction for the field. It unshackles itself from some of the constraints inherent in some of the more traditional strategy research approaches, allowing strategy practitioners to assume a more central role on the research agenda.

Researchers are enamoured with a staunch belief that the choice of a SAP perspective as a tool to incorporate within the wider study's case study methodology is of merit. This view is supported by the growing popularity of the practice-as-a-perspective mode, its inherent suitability of situating the practitioner in context and linking micro and macro-level activity, the existence of a pedagogically digestible strategy-themed theory to guide the study in the form of Whittington's (2006) 3Ps framework, and its suitability to 'address organisational phenomena that are posited to be relational, dynamic, and emergent' (Orlikowski, 2010: 27).

\section{INCORPORATING RIGOUR, RELEVANCE, AND QUALITY: THE ROLE OF THE CHOSEN RESEARCH APPROACH}

The rigour versus relevance debate has been hotly contested in academic publications (Desouza et al., 2006; Fällman and Grönlund, 2002; Gioia et al., 2012; Robey and Markus, 1998; Straub and Ang, 2011). Indeed, it is particularly pertinent for the current study and its adopted research approach. With IS being an applied discipline, this debate has been particularly fervent within the IS community. The main crux of the argument centres on whether IS research can maintain its academic rigour and legitimacy while being in possession of relevancy for the practitioner community. This duality is one with which the discipline has struggled. Knowing one's target audience is crucial in attempting to overcome such a hurdle. As defined by Fällman and Grönlund (2002, n. pg.), 'Rigor denotes a structured and controlled way of planning, carrying out, analysing, evaluating and producing products of research, independently of the research method used.' Fällman and Grönlund (2002, n. pg.) define relevance as 'the act of making efforts into research issues that is of concern to a perceived audience'.

The current study's investigation into the practice of SISP by senior managers follows the sentiments of authors, inclusive of Fällman and Grönlund (2002) and Robey and Markus (1998), in that rigour and relevance need not be seen as competing ideals but rather may be realised in tandem. The incorporation of a SAP perspective furnishes the study with a relevancy to practitioners while also benefitting from the rigourous empirical investigatory tools afforded by a strict adherence to a robust case study methodology.

Remaining faithful to the chosen methodology's prescriptions, inclusive of the maintenance of a clear chain of evidence chronicling the researchers' activities, imbued the study with a defined structure. The SAP lens further instilled a consistency and uniformity of action, focussing data collection and analysis within the broader case study methodology upon those elements most critical for the answering of the research question. This was achieved though the study's anchoring upon the 'doing' or praxis of the strategy work (Whittington, 2006), routinised behaviour in the form of practices (i.e. the practice of SISP), and a focus upon IS strategy's practitioners (in this instance, senior managers). Levels of activity (Jarzabkowski and Spee, 2009) and strategic episodes (predominantly comprising strategic meetings) were all concepts that practitioners could relate to and easily understand.

Having decided upon the case study methodology, a SAP perspective infiltrated the core sources of evidence employed during data collection, thus reaffirming the rigourous approach employed while maintaining relevancy to the practitioner. Documentation, archival materials, and physical artefacts were distilled into a multi-level design (Kozlowski et al., 2013) consisting of macro, meso, and micro categories. Specific practices were discerned from each source, as were the practitioners involved and the praxis that transpired. The interviewing process was also formatted to examine activity at the macro, meso, and micro levels. The practices associated with SISP, the practitioners involved, the praxis that actually took place in the employed case sites, and strategic episodes represented specific topics of discussion.

Subsequently, the rich resources of primary and secondary data accrued were analysed through a SAP lens. The researchers were able to move with confidence through the large quantities of collected data armed with a 
comprehensive knowledge of the key elements of which to be aware. The rigour afforded by the implementation of a theoretically driven case study methodology, combined with the relevancy imbued through the implementation of a SAP lens, instilled a novelty to the research approach. It has resulted in a programme of research that the researchers are confident belies the notion that rigour and relevance need to be mutually exclusive.

\section{Ensuring quality}

The topic of quality in IS research has been a feature of the extant literature (Conboy et al., 2012; Galliers and Huang, 2012; Klein and Myers, 1999). It has also been a feature of the more generalised prescriptions on the conduct of casework and the methodology's tools for establishing validity (Stake, 1995; Yin, 2009; Zivkovic, 2012). Empirical research conducted within the social sciences realm has a recognised set of parameters by which quality can be established (Yin, 2009). Each of these four tests has specified tactics by which researchers can be guided for case-based studies. The tests are as follows:

- Construct validity: it involves the identification of appropriate operational measures for the topic of investigation.

- Internal validity: it seeks to establish a causal relationship and is used only for explanatory or causal studies and not for descriptive or exploratory studies. Due to the exploratory nature of the current study, this test does not directly apply.

- External validity: this defines the parameters within which the research findings may be generalised.

- Reliability: This construct ascertains whether the study's findings can be replicated should the same procedures be followed.

(Adapted from Yin, 2009)

For the current study, the three applicable tests are construct validity, external validity, and reliability. Internal validity is primarily a concern for the case study researcher who wishes to explain how and why $x$ leads to $y$, i.e. a causal case, which is not a feature of the employed research approach. To view how the researchers established quality, Table 5 provides an overview of the measures taken to ensure that each test was sufficiently satisfied.

Table 5. Ensuring quality: measures taken to establish validity (adapted from Yin, 2009)

\begin{tabular}{ll}
\hline Tests & \multicolumn{1}{c}{ Case study tactic } \\
\hline $\begin{array}{l}\text { Construct } \\
\text { validity }\end{array}$ & $\begin{array}{l}\text { Multiple sources of evidences were collected in the form of interviews, documentation, archival } \\
\text { records, and physical artefacts. } \\
\text { A clear chain of evidence has been established. } \\
\text { The individual case study reports have been reviewed and verified by key informants from the } \\
\text { employed case studies. }\end{array}$ \\
$\begin{array}{l}\text { External } \\
\text { validity }\end{array}$ & $\begin{array}{l}\text { A replication logic was employed in the form of literal replication, with similar results expected at the } \\
\text { outset of the study. }\end{array}$ \\
& $\begin{array}{l}\text { A defined protocol was established, of which the researchers were cognisant throughout the conduct } \\
\text { of the study. The sequencing of data collection, the methods by which data collection and analysis } \\
\text { were undertaken, and appropriate ethical considerations were observed. } \\
\text { A case study database was established through the use of Nvivo, the chosen qualitative analysis } \\
\text { software. This resource was supplemented by extensive libraries of pertinent case data stored both } \\
\text { locally and in cloud-based storage. }\end{array}$ \\
\hline
\end{tabular}

\section{DISCUSSION: REFLECTIONS ON THE USE OF THE CASE STUDY METHODOLOGY FOR THE STUDY OF STRATEGY PRACTICE}

The authors have cultivated a number of reflections accrued from their experiences with the case study methodology during the conduct of the wider study.

To begin, the framing of a SAP-oriented research question is of paramount importance. A familiarisation with the wider theoretical underpinnings of the domain (Bourdieu, 1990; Foucault, 1980; Giddens, 1976; Heidegger, 1962; Wittgenstein, 1951), in addition to the conceptual base of the SAP field (Jarzabkowski et al., 2007; Whittington, 2002, 2006), is a prerequisite for research of this nature. The case study methodology alone was found to lack a coherent 
integrative mechanism with which to answer the research question posed. While widely cited prescriptive texts (Stake, 1995; Yin, 2009) exist to detail the various tools, techniques, and methods that comprise the methodology, an inherent vagueness was found to prevail as to how such a study would be rendered operational. The adoption of a SAP perspective in conjunction with the case study methodology was found to counteract this shortcoming, providing a robust framework (Whittington, 2006) upon which the research could be based.

At the core of a practice-based study is the requirement to link specific levels of activity. While the case study methodology alone could be used for this research goal, it was only when a practice lens was applied that the authors were able to precisely identify and target those components crucial to the practice of SISP by senior managers. A clear delineation of the levels at which praxis transpires is imperative. The wider study adopted the categorisation of micro, meso, and macro levels (Jarzabkowski and Spee, 2009). While a precision on the part of the researchers is required to make explicit the boundaries of each level, the pervasive nature of activity both between and across levels forms a key attribute of SAP-based research (Johnson et al., 2007). The ultimate dividend is a refinement often found lacking in rudimentary casework.

The core tenets of SAP were continuous threads running throughout the entire study. As an integrating mechanism, it was found to instil coherence to the process. Initially, it provided a lens through which to conduct a review of the SISP literature (Hughes and McDonagh, 2014), proving to be both a clinical and a novel approach. While the core elements of a SAP perspective are not explicit within the SISP literature, the casting of such a lens over the domain revealed their presence in a tangible, if not disjointed, form. In addition, the SAP perspective formed a core element of both data collection and analysis. From a data collection standpoint, a SAP-based study must remain diligent to the concept of levels. Decisions need to be made concerning the type of data and the particular levels at which they need to be collected. In regard to data analysis, the onus is on the researchers to first apply their analytical focus to individual levels, before searching for extant linkages both between and across multiple levels. The establishment of a clear chain of evidence is a fundamental requirement for such an endeavour.

In terms of a limitation of the current study, it follows a prevalent trend within the SAP domain of not precisely complying with the ethnographic approach often espoused within the prescriptive literature. Ethnography has been widely lauded as an ideal match for the study of strategy practice (Chia and MacKay, 2007; Fenton and Langley, 2011; Jarzabkowski et al., 2007). However, a mere nine studies out of the 48 empirical works reviewed within the domain employed an ethnographic approach. In contrast, the research is dominated by either single-case studies (21) or a small number of multiple-case studies (17). The researchers are confident that a sustained commitment to executing rigourous casework, in conjunction with the interweaving of a SAP perspective throughout all major elements of the research design, has compensated for any perceived shortcomings attributable to the non-utilisation of an ethnographic approach.

Finally, combining the case study methodology with a SAP perspective is a novel approach within the SISP domain. Although the SAP perspective finds itself in a relatively nascent stage of its academic tenure, it has garnered a favourable response from scholarly ranks (Whittington, 2014). During immersion in the field, it was also discovered to have an ability to speak directly to the practitioner. Thus, it inhabits a comfortable equilibrium within the rigour versus relevance debate that has pervaded much of the wider IS literature (Fällman and Grönlund, 2002; Petter et al., 2012). It is hoped that the many benefits it imbues will encourage fellow researchers to consider underpinning core casework with a robust theoretical perspective, be it practice based or otherwise.

\section{References}

Amaratunga, D. and Baldry, D. (2001). 'Case study methodology as a means of theory building: Performance measurement in facilities management organisations'. Work Study, 50: 3, 95-104.

Applegate, L.M. and Elam, J.J. (1992). 'New information systems leaders: A changing role in a changing world'. MIS Quarterly, 16: 4, 469-490.

Avgerou, C. and McGrath, K. (2007). 'Power, rationality, and the art of living through socio-technical change'. MIS Quarterly, 31: 2, 295-315.

Avison, D., Dwivedi, Y., Fitzgerald, G. and Powell, P. (2008). 'The beginnings of a new era: Time to reflect on 17 years of the ISJ'. Information Systems Journal, 18: 1, 5-21.

Balogun, J., Jacobs, C., Jarzabkowski, P., Mantere, S. and Vaara, E. (2014). 'Placing strategy discourse in context: Sociomateriality, sensemaking, and 
power'. Journal of Management Studies, 51: 2, 175-201.

Barua, A., Kriebel, C.H. and Mukhopadhyay, T. (1991). 'An economic analysis of strategic information technology investments'. MIS Quarterly, 15: 3, 313331.

Benbasat, I., Goldstein, D.K. and Mead, M. (1987). 'The case research strategy in studies of information systems'. MIS Quarterly, 11: 3, 369-386.

Bourdieu, P. (1990). The Logic of Practice, Cambridge: Polity Press.

Brown, I.T.J. (2004). 'Testing and extending theory in strategic information systems planning through literature analysis'. Information Resources Management Journal, 17: 4, 20-48.

Browne, S., Sharkey-Scott, P., Mangematin, V., Lawlor, K. and Cuddihy, L. (2014). 'Adapting a book to make a film: How strategy is adapted through professional practices of marketing middle managers'. Journal of Marketing Management, 30: 9-10, 949-973.

Bryman, A. (2007). 'The research question in social research: What is its role?'. International Journal of Social Research Methodology, 10: 1, 5-20.

Bryson, J.M., Berry, F.S. and Yang, K. (2010). 'The state of public strategic management research: A selective literature review and set of future directions'. The American Review of Public Administration, 40: 5, 495-521.

Bürgi, P.T., Jacobs, C.D. and Roos, J. (2005). 'From metaphor to practice : In the crafting of strategy'. Journal of Management Inquiry, 14: 1, 78-94.

Campbell-Hunt, C. (2007). 'Complexity in practice.' Human Relations, 60: 5, 793-823.

Carroll, B., Levy, L. and Richmond, D. (2008). 'Leadership as practice: Challenging the competency paradigm'. Leadership, 4: 4, 363-379.

Cecez-Kecmanovic, D., Galliers, R.D., Henfridsson, O., Newell, S. and Vidgen, R. (2014). 'The sociomateriality of information systems: current status, future directions'. MIS Quarterly, 38: 3, 809-830.

Chan, Y.E. and Reich, B.H. (2007). 'IT alignment: What have we learned?'. Journal of Information Technology, 22: 4, 297-315.

Charmaz, K. (2006). Constructing Grounded Theory: A Practical Guide Through Qualitative Analysis, Thousand Oaks, CA: Sage.

Chen, D.Q., Mocker, M. and Teubner, A. (2010). 'Information systems strategy: reconceptualization, measurement, and implications'. MIS Quarterly, 34: 2, 233-259.

Chen, W. and Hirschheim, R. (2004). 'A paradigmatic and methodological examination of information systems research from 1991 to 2001'. Information Systems Journal, 14: 3, 197-235.

Chia, R. (2006). 'Strategy as practical coping: A Heideggerian perspective'. Organization Studies, 27: 5, 635-655.

Chia, R. and MacKay, B. (2007). 'Post-processual challenges for the emerging strategy-as-practice perspective: Discovering strategy in the logic of practice'. Human Relations, 60: 1, 217-242.

Clegg, S., Kornberger, M. and Rhodes, C. (2007). 'Business ethics as practice'. British Journal of Management, 18: 2, 107-122.

Conboy, K., Fitzgerald, G. and Mathiassen, L. (2012). 'Qualitative methods research in information systems: Motivations, themes, and contributions'. European Journal of Information Systems, 21: 2, 113-118.

Corbin, J. and Strauss, A. (2008). Basics of Qualitative Research: Techniques and Procedures for Developing Grounded Theory, 3rd edn., Thousand Oaks, CA: Sage.

Darke, P., Shanks, G. and Broadbent, M. (1998). 'Successfully completing case study research: Combining rigour, relevance and pragmatism'. Information Systems Journal, 8: 4, 273-289.

De Certeau, M. (1984). The Practice of Everyday Life, Berkeley: University of California Press.

Denzin, N.K. and Lincoln, Y.S. (2005). 'Introduction: The discipline and practice of qualitative research', in Handbook of Qualitative Research, 3rd edn., Vol. 2, Thousand Oaks, CA: Sage, pp.1-32.

Deslandes, G. (2011). 'Wittgenstein and the practical turn in business ethics'. Electronic Journal of Business Ethics and Organization Studies, 16: 1, 48-54.

Desouza, K.C., El Sawy, O.A., Galliers, R.D., Loebbecke, C. and Watson, R.T. (2006). 'Beyond rigor and relevance towards responsibility and reverberation: Information systems research that really matters'. Communications of the Association for Information Systems, 17, 341-353.

Doolin, B. (1996). 'Alternative views of case research in information systems'. Australasian Journal of Information Systems, 3: 2, 21-29.

Eisenhardt, K.M. (1989). 'Building theories from case study research'. The Academy of Management Review, 14: 4, 532-550.

Eisenhardt, K.M. and Graebner, M.E. (2007). 'Theory building from cases: opportunities and challenges'. The Academy of Management Journal, 50: 1, 2532.

Eng, T. and Luff, P. (2011). 'Competing and developing competitive advantage in the digital world'. 
Technology Analysis \& Strategic Management, 23: 9, 947-950.

Fällman, D. and Grönlund, A. (2002). 'Rigor and relevance remodeled', in Proceedings of Information Systems Research in Scandinavia, Vol. 23, p. n. pag.

Feldman, M.S. and Orlikowski, W.J. (2011). 'Theorizing practice and practicing theory'. Organization Science, 22: 5, 1240-1253.

Fenton, C. and Langley, A. (2011). 'Strategy as practice and the narrative turn'. Organization Studies, 32: 9, 1171-1196.

Foucault, M. (1980). Power/Knowledge: Selected Interviews and Other Writings 1972-1977, New York: Pantheon.

Franklin, R.D., Allison, D.B. and Gorman, B.S. (2014). Design and Analysis of Single-Case Research, New York: Psychology Press.

Gable, G.G. (1994). 'Integrating case study and survey research methods: An example in information systems'. European Journal of Information Systems, 3: 2, 112-126.

Galliers, R.D. (1993). 'Research issues in information systems'. Journal of Information Technology, 8: 2, 92-98.

Galliers, R.D. and Huang, J.C. (2012). 'The teaching of qualitative research methods in information systems: An explorative study utilizing learning theory'. European Journal of Information Systems, 21: 2, 119-134.

Gerring, J. (2004). 'What is a case study and what is it good for?'. The American Political Science Review, 98: 2, 341-354.

Giddens, A. (1976). New Rules of Sociological Method, London: Hutchinson.

Giddens, A. (1984). The Constitution of Society, Cambridge, U.K.: Polity Press.

Gioia, D.A., Corley, K.G. and Hamilton, A.L. (2012). 'Seeking qualitative rigor in inductive research: Notes on the Gioia methodology'. Organizational Research Methods, 16: 1, 15-31.

Glaser, B. and Strauss, A. (1967). The Discovery of Grounded Theory: Strategies of Qualitative Research, London: Wledenfeld and Nicholson.

Gunn, R. and Williams, W. (2007). 'Strategic tools : An empirical investigation into strategy in practice in the UK'. Strategic Change, 16: 5 August, 201216.

Hardy, C. and Thomas, R. (2014). 'Strategy, discourse and practice: The intensification of power'. Journal of Management Studies, 51: 2, 320-348.

Heidegger, M. (1962). Being and Time, Oxford: Blackwell.
Henderson, J. and Venkatraman, N. (1993). 'Strategic alignment: Leveraging information technology for transforming organizations'. IBM Systems Journal, 32: 1, 472-484.

Hendry, J. (2000). 'Strategic decision making, discourse, and strategy as social practice'. Journal of Management Studies, 37: 7, 955-977.

Hendry, J. and Seidl, D. (2003). 'The structure and significance of strategic episodes: Social systems theory and the routine practices of strategic change'. Journal of Management Studies, 40: 1, 175-196.

Hermanowicz, J.C. (2002). 'The great interview: 25 strategies for studying people in bed'. Qualitative Sociology, 25: 4, 479-499.

Hirschheim, R. and Klein, H.K. (2012). 'A glorious and not-so-short history of the information systems field'. Journal of the Association for Information Systems, 13: 4, 188-235.

Hoon, C. (2013). 'Meta-synthesis of qualitative case studies: An approach to theory building'. Organizational Research Methods, 16: 4, 522-556.

Hughes, J. and McDonagh, J. (2014). 'New avenues in strategic information systems planning research: A strategy as practice perspective', in British Academy of Management Conference 2014 Proceedings, Belfast Waterfront, Belfast, Northern Ireland.

Jarratt, D. and Stiles, D. (2010). 'How are methodologies and tools framing managers' strategizing practice in competitive strategy development?'. British Journal of Management, 21: 1, 28-43.

Jarzabkowski, P. (2003). 'Strategic practices: An activity theory perspective on continuity and change'. Journal of Management Studies, 40: 1, 23-55.

Jarzabkowski, P. (2008). 'Shaping strategy as a structuration process'. Academy of Management Journal, 51: 4, 621-650.

Jarzabkowski, P., Balogun, J. and Seidl, D. (2007). 'Strategizing: The challenges of a practice perspective'. Human Relations, 60: 1, 5-27.

Jarzabkowski, P. and Seidl, D. (2008). 'The role of strategy meetings in the social practice of strategy'. Organization Studies, 29: 11, 1391-1426.

Jarzabkowski, P. and Spee, A.P. (2009). 'Strategy as practice: A review and future directions for the field'. International Journal of Management Reviews, 11: 1, 69-95.

Jarzabkowski, P. and Whittington, R. (2008). 'Hard to disagree, mostly'. Strategic Organization, 6: 1, 101-106.

Johnson, G., Langley, A., Melin, L. and Whittington, R. (2007). Strategy as practice: Research directions 
and resources. Cambridge: Cambridge University Press.

Johnson, G., Melin, L. and Whittington, R. (2003). 'Guest editors' introduction - Micro strategy and strategizing: Towards an activity-based view'. Journal of Management Studies, 40: 1, 3-22.

Kearns, G. and Lederer, A. (2000). 'The effect of strategic alignment on the use of IS-based resources for competitive advantage'. The Journal of Strategic Information Systems, 9: 4, 265-293.

Klein, H.K. and Myers, M.D. (1999). 'A set of principles for conducting and evaluating interpretive field studies in information systems'. MIS Quarterly, 23: 1, 67-93.

Kornberger, M. and Carter, C. (2010). 'Manufacturing competition: How accounting practices shape strategy making in cities'. Accounting, Auditing \& Accountability Journal, 23: 3, 325-349.

Kozlowski, S.W.J., Chao, G.T., Grand, J.A., Braun, M.T. and Kuljanin, G. (2013). 'Advancing multilevel research design: capturing the dynamics of emergence'. Organizational Research Methods, 16: 4, 581-615.

Kuhn, T.S. (1987). 'What are scientific revolutions?', in L. Kruger, L.J. Daston and M. Heidelberger (eds), The Probabilistic Revolution, Vol. 1: Ideas in History. Cambridge, MA: MIT Press, pp.7-22.

Kvale, S. (1996). Interviews: An Introduction to Qualitative Research Interviewing, London: Sage Publications, Inc.

Lederer, A.L. and Mendelow, A.L. (1989). 'Coordination of information systems plans with business plans'. Journal of Management Information Systems, 6: 2, 5-19.

Lederer, A.L. and Sethi, V. (1996). 'Key prescriptions for strategic information systems planning'. Jounral of Management Information Systems, 13: 1, 35-62.

Lee, A.S. (1989). 'A scientific methodology for MIS case studies'. MIS Quarterly, 13: 1, 33-50.

Lee, A.S. and Hubona, G.S. (2009). 'A scientific basis for rigor in information systems research'. MIS Quarterly, 33: 2, 237-262.

Leidner, D.E., Lo, J. and Preston, D. (2011). 'An empirical investigation of the relationship of IS strategy with firm performance'. Journal of Strategic Information Systems, 20: 4, 419-437.

Maclntyre, A. (1985). After Virtue, 2nd edn., London: Duckworth.

Maykut, P. and Morehouse, R. (1994). Beginning Qualitative Research: A Philosophic and Practical Guide, London: The Falmer Press.

Merali, Y., Papadopoulos, T. and Nadkarni, T. (2012). 'Information systems strategy: Past, present, future?'. The Journal of Strategic Information Systems, 21: 2, 125-153.

Miettinen, R., Samra-Fredericks, D. and Yanow, D. (2010). 'Re-turn to practice: An introductory essay'. Organization Studies, 30: 12, 1309-1327.

Miles, M.B. and Huberman, A.M. (1994). Qualitative Data Analysis: An Expanded Sourcebook, 2nd ed., Thousand Oaks, CA: Sage.

Mingers, J. (2001). 'Combining IS research methods: Towards a pluralist methodology'. Information Systems Research, 12: 3, 240-259.

Mojtahed, R., Nunes, M.B., Martins, J.T. and Peng, A. (2014). 'Equipping the constructivist researcher: The combined use of semi-structured interviews and decision-making maps'. Electronic Journal of Business Research Methods, 12: 2, 87-95.

Myers, M. (1999). 'Investigating information systems with ethnographic research'. Communications of the Association for Information Systems, 2: 23, 1-20.

Myers, M. and Newman, M. (2007). 'The qualitative interview in IS research: Examining the craft'. Information and Organization, 17: 1, 2-26.

Myers, M. and Venable, J.R. (2014). 'A set of ethical principles for design science research in information systems'. Information and Management, 51: 6, 801-809.

Okpattah, B.K., Chisenga, J. and Otoo, R. (2014). 'Information Systems' contribution to firm performance: Impacts of information systems strategy and IS maturity'. Information and Knowledge Management, 4: 12, 73-83.

Oliver, D. and Bürgi, P. (2005). 'Organizational identity as a strategic practice', in 4th International Critical Management Studies Conference, Cambridge, U.K., pp.1-26.

Orlikowski, W. and Baroudi, J.J. (1991). 'Studying information technology in organizations: Research approaches and assumptions'. Information Systems Research, 2: 1, 1-28.

Orlikowski, W.J. (2010). 'Practice in research: Phenomenon, perspective and philosophy', in D. Golsorkhi, L. Rouleau, D. Seidl and E. Vaara (eds), Cambridge Handbook of Strategy as Practice, 1st edn., Cambridge, U.K.: Cambridge University Press, p.349.

Palmer, M. and O'Kane, P. (2007). 'Strategy as practice: Interactive governance spaces and the corporate strategies of retail transnationals'. Journal of Economic Geography, 7: 4, 515-535.

Palvia, P., Pinjani, P. and Sibley, E. (2007). 'A profile of information systems research published in information \& management'. Information and Management, 44: 1, 1-11. 
Peppard, J., Galliers, R.D. and Thorogood, A. (2014). 'Information systems strategy as practice: Micro strategy and strategizing for IS'. Journal of Strategic Information Systems, 23: 1, 1-10.

Perry, C. (1998). 'Processes of a case study methodology for postgraduate research in marketing'. European Journal of Marketing, 32: 9/10, 785-802.

Petter, S., DeLone, W. and McLean, E.R. (2012). 'The past, present, and future of "IS success"'. Journal of the Association for Information Systems, 13: (Special Issue), 341-362.

Piccoli, G. and Ives, B. (2005). 'Review: IT-dependent strategic initiatives and sustained competitive advantage: A review and synthesis of the literature.' MIS Quarterly, 29: 4, 747-776.

Poulis, K., Poulis, E. and Plakoyiannaki, E. (2013). 'The role of context in case study selection: An international business perspective'. International Business Review, 22: 1, 304-314.

Powell, T. and Dent-Micallef, A. (1997). 'Information technology as competitive advantage: The role of human, business, and technology resources'. Strategic Management Journal, 18: 5, 375-405.

Preston, D.S. and Karahanna, E. (2006). 'Development of shared understanding between the chief information officer and top management team in US and French organizations: A cross-cultural comparison'. IEEE Transactions on Engineering Management, 53: 2, 191-206.

Raelin, J.A. (2011). 'From leadership-as-practice to leaderful practice'. Leadership, 7: 2, 195-211.

Rasche, A, and Chia, R. (2009). 'Researching strategy practices: Agenealogical social theory perspective'. Organization Studies, 30: 7, 713-734.

Ravichandran, T. and Lertwongsatien, C. (2005). 'Effect of information systems resources and capabilities on firm performance: A resource-based perspective'. Journal of Management Information Systems, 21: 4, 237-276.

Regner, P. (2008). 'Strategy-as-practice and dynamic capabilities: Steps towards a dynamic view of strategy'. Human Relations, 61: 4, 565-588.

Robey, D. and Markus, M.L. (1998). 'Beyond rigor and relevance: Producing consumable research about information systems'. Information Resources Management Journal, 11: 1, 7-15.

Rocheleau, B. (2007). 'Whither e-government?'. Public Administration Review, 67: 3, 584-588.

Rubin, B.M. (1986). 'Information systems for public management: Design and implementation'. Public Administration Review, 46: Special Issue, 540-552.

Sandberg, J. and Dall'Alba, G. (2010). 'Returning to practice anew: A life-world perspective'.
Organization Studies, 30: 12, 1349-1368.

Schatzki, T. (1996). Social Practices: A Wittgensteinian Approach to Human Activity and the Social, Cambridge: CUP.

Schultze, U. and Avital, M. (2010). 'Designing interviews to generate rich data for information systems research'. Information and Organization, 1-16.

Segars, A.H., Grover, V. and Teng, J.T. C. (1998). 'Strategic information systems planning: planning dimensions, internal coalignment, and implications for planning effectiveness'. Decision Sciences, 29: 2, 303-345.

Seidl, D. and Whittington, R. (2014). 'Enlarging the Strategy-as-practice research agenda: Towards taller and flatter ontologies'. Organization Studies, 8: 35, 1-15.

Senn, J. (1998). 'The challenge of relating IS research to practice'. Information Resources Management Journal, 11: 1, 23-28.

Siggelkow, N. (2007). 'Persuasion with case studies'. Academy of Management Journal, 50: 1, 20-24.

Splitter, V. and Seidl, D. (2011). 'Does practice-based research on strategy lead to practically relevant knowledge? Implications of a Bourdieusian perspective'. The Journal of Applied Behavioral Science, 47: 1, 98-120.

Stace, D., Courtney, N. and Holtham, C. (2012). 'Bringing ICT to the strategy table'. Strategic Change, 21: 1-2, 41-57.

Stahl, B.C., Eden, G., Jirotka, M. and Coeckelbergh, M. (2014). 'From computer ethics to responsible research and innovation in ICT the transition of reference discourses informing ethics-related research in information systems'. Information and Management, 51: 6, 810-818.

Stake, R.E. (1995). The Art of Case Study Research, Thousand Oaks, CA: Sage.

Steventon, A., Jackson, T.W., Hepworth, M., Curtis, S. and Everitt, C. (2012). 'Exploring and modelling elements of information management that contribute towards making positive impacts: An outcome based approach for senior managers in a local government setting'. International Journal of Information Management, 32: 2, 158-163.

Straub, D. and Ang, S. (2011). 'Rigor and relevance in IS research: Redefining the debate and a call for future research'. MIS Quarterly, 35: 1, iii-xi.

Teubner, R.A. (2013). 'Information systems strategy'. Business \& Information Systems Engineering, 5: 4, 243-257.

Tsang, E.W.K. (2013). 'Case study methodology: Causal explanation, contextualization, and theorizing'. Journal of International Management, 19: 2, 195-202. 
Tsang, E.W. K. (2014). 'Case studies and generalization in information systems research: A critical realist perspective'. The Journal of Strategic Information Systems, 23: 2, 174-186.

Vaara, E. and Whittington, R. (2012). 'Strategy-aspractice: Taking social practices seriously'. The Academy of Management Annals, 6: 1, 285-336.

Van de Ven, A.H. and Huber, G.P. (1990). 'Longitudinal field research methods for studying processes of organizational change'. Organization Science, 1: 3, 213-219.

Venkatesh, V., Brown, S.A. and Bala, H. (2013). 'Bridging the qualitative-quantitative divide: Guidelines for conducting mixed methods research in information systems'. MIS Quarterly, 37: 1, 21-54.

Vessey, I., Ramesh, V. and Glass, R.L. (2002). 'Research in information systems: An empirical study of diversity in the discipline and its journals'. Journal of Management Information Systems, 19: 2, 129-174.

Ward, J.M. and Peppard, J. (2002). Strategic Planning for Information Systems, 3rd edn., Chichester, U.K.: John Wiley \& Sons.

Watson, T.J. (2011). 'Ethnography, reality, and truth: The vital need for studies of "How Things Work" in organizations and management'. Journal of Management Studies, 48: 1, 202-217.

Whittington, R. (2002). 'Practice perspectives on strategy: Unifying and developing a field', in Academy of Management Proceedings, pp.1-6.

Whittington, R. (2004). 'Strategy after modernism:
Recovering practice'. European Management Review, 1: 1, 62-68.

Whittington, R. (2006). 'Completing the practice turn in strategy research'. Organization Studies, 27: 5, 613-634.

Whittington, R. (2007). 'Strategy practice and strategy process: Family differences and the sociological eye'. Organization Studies, 28: 10, 1575-1586.

Whittington, R. (2014). 'Information systems strategy and strategy-as-practice: A joint agenda'. Journal of Strategic Information Systems Planning, In Press.

Whittington, R., Cailluet, L. and Yakis-Douglas, B. (2011). 'Opening strategy: Evolution of a precarious profession'. British Journal of Management, 22: 2, 531-544.

Williams, M., Dwivedi, Y., Lal, B. and Schwarz, A. (2009). 'Contemporary trends and issues in IT adoption and diffusion research'. Journal of Information Technology, 24: 1, 1-10.

Wittgenstein, L. (1951). Philosophical Investigations, Oxford: Basil Blackwell.

Yin, R.K. (1994). Case Study Research: Design and Methods, 2nd edn., Beverly Hills, CA.: Sage Publishing, Inc.

Yin, R.K. (2009). Case Study Research: Design and Methods, 4th edn., Thousand Oaks, CA: Sage Publications, Inc.

Zivkovic, J. (2012). 'Strengths and weaknesses of business research methodologies: Two disparate case studies'. Business Studies Journal, 4: 2, 91100. 